\title{
THE ASSESSMENT AND REDUCTION OF SEISMIC RISK: TOWARDS A SYSTEM OF KNOWLEDGE FOR ARCHAEOLOGICAL PRE- EXISTENCES
}

\author{
E. MONTENEGRO* \\ * Department of History, Design and Restoration of Architecture \\ Sapienza University of Rome \\ Piazza Borghese 9, 00186 Rome, Italy \\ e-mail: elisabetta.montenegro@uniroma1.it
}

Keywords: Archaeology, Seismic Vulnerability, Risk Assessment, Territorial Scale Analysis

\begin{abstract}
The earthquake is a serious risk factor for archaeological heritage and, especially in this thematic area, the preventive protection assumes a strategic importance due to the lack of purpose that a reconstructive intervention would produce. However, the multiple problems of conservation and enhancement of the archeological heritage make the planning of damage mitigation complex, according to the criteria adopted for historical architecture.

From the evolutionary framework of the sectoral regulations in Italy emerges a generic extension of the provisions for specific architectural monuments to the archaeological ones, in which the absence of connections or their intrinsic weakness, if any, increases their vulnerability.

Currently, it is clear that the absence of a specific "functional connotation" of ruins, apart from the visit one, places these contexts on the margin of the most recent regulations reconsiderations. Indeed, the current Linee Guida Mibact 2011 (Mibact Guidelines 2011) introduce a rapid evaluation methodology on a territorial scale $\left(L_{V I}\right)$ which does not consider the archaeological structures.

The paper proposes a rapid assessment method for the archaeological seismic vulnerability, which tries to connect the knowledge system with the analytical result on a territorial scale. This approach, based on a hierarchical system identification of structural 'morphos-types', is developed with applications conducted on the Roman Forum structures. Specifically, the attention is focused on the ruins constituted by walls without connections, whose structural behaviour, far from the global one, can be assimilated to a 'macro-element'. The seismic risk assessment is set according to the Carta del Rischio (the Risk Map) system methodology. This method introduces an algorithm for calculating structural vulnerability able to grasp the constructive and conservative specificities that influence the structural behaviour of the archaeological pre-existences.
\end{abstract}




\section{THE SEISMIC RISK PROBLEM FOR THE ARCHAEOLOGICAL HERITAGE}

The seismic risk and the archaeological heritage have always lapped. On the one hand, the weak prevention, which often transforms the natural event into a catastrophic moment, inevitably focuses the attention on the historical architecture still in use. On the other hand, the complexities related to the conservation and enhancement of these pre-existences overshadow the reflections on exceptional events like the earthquake and, consequently, the planning of damage mitigation according to the criteria adopted for historical architecture. However, the earthquake preventive protection assumes strategic importance due to the loss of meaning that a reconstructive intervention would produce.

When we talk about archaeological ruins, we usually refer to structures whose height does not exceed four meters, in which the instabilities caused by the earthquake rarely damage visitors. However, the large monumental complexes (temples, amphitheaters, baths) are an exception. The morphological complexity and the geometric relationships of their structures amplify their vulnerability. In these cases, the potential risk has been managed for a long time by implementing provisions such as the limitation of using and approaching the monument. However, an exceptional event such as the earthquake, which is intrinsic with the geological nature of the Italian territory, represents a risk not only for the public safety of the users but also for the material conservation of the monument itself. Nevertheless, with the exception of singular structures, for a long time the archaeological heritage seismic risk has been managed as a secondary problem with respect to the more general conservative needs and the first

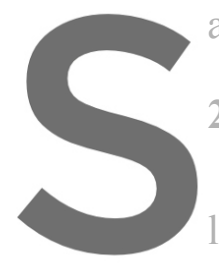
attention to the topic

2 THE EVOLUTIONARY

In the last years of th legislation on the preven
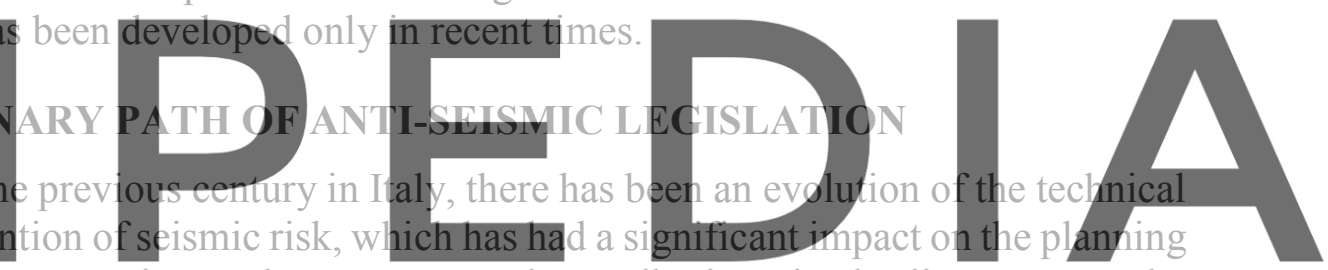

of historical building interventions. There are several contributions in the literature on the

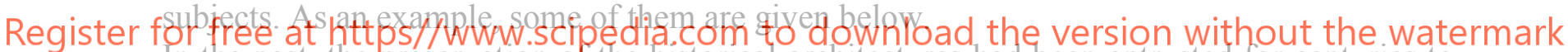
In the past, the preservation of the historical architectures had been entrusted for centuries to continuous control, through the introduction of corrections suggested by the periodic observation of the structural behaviour, or through the experimentation of reinforcement techniques when a new instability arose. Starting from the end of the XVIII century and throughout the XIX century, this tradition was implemented in the first anti-seismic regulations [1]. With the advent of new construction technologies, the first seismological researches and the first studies on the dynamic behaviour of buildings, the need to conduct safety checks arose, giving a scientific aspect to the legislation [2]; but the attention to the historical and monumental heritage is the result of a gradual process of awareness-raising on the theme, which became explicit only in the early 1980 s.

Indeed, the first seismic regulation of 1909 [3], provided for the adoption of the new building rules in case of repair of masonry constructions, with the only possibility for protected buildings to apply the "case by case" criterion. Although the historic building was formally excluded from specific obligations, in many cases the need for a discreet structural safety led to the adoption of technologically invasive solutions, regardless of the competences attributed to the Superintendencies by the Law 1089 of 1939 [4] or by the contents of the Restoration Papers of those years (Athens 1931, Venice 1964). The heavy impacts, produced both on the minor 
building and on the monumental heritage, immediately demonstrate the limits of the 1981 regulation, which establishes 'seismic adjustment' [5] in repairing post-earthquake damage. With the Raccomandazioni of 1986 (Recommendations) [6], a technical-cultural reflection on the conservation of historical and monumental heritage is articulated for the first time, introducing the concept of 'improvement', conveyed through alternative and less invasive interventions, acquired by reflection from the seismic regulation of 1986 [7]. It is in this context that starts a different and more effective attention to the archaeological pre-existences theme, with the idea of excluding them from the application of the rules valid for ordinary buildings. This attention is explicit in the document drawn up during the National Seismic Engineering Conference of 1991, which took place in Palermo [8]. However, the non-approval of the document causes the marginalization of this issue in the following rules, as evidenced by the Ministerial Decree of 1996 [9], with the result that the practice has recklessly continued to extend the current architecture provisions to the archaeological heritage. If, with the redefinition of the entire national territory seismic risk of 2003 [10] were introduced more stringent structural checks even for protected buildings, the Norme Tecniche per le Costruzioni of 2008 (Technical Regulations for Constructions) [11] clarify the difference between 'improvement' and 'adjustment' in the possibility of 'improving' a historic building by seeking a balance between conservation and structural safety. The Linee Guida per la valutazione e riduzione del rischio sismico del patrimonio culturale (Mibact 2011) [12] translate this concept by outlining a methodological tool for the knowledge, the diagnosis and the project of conservation. The choice of an appropriate level of safety to be achieved by controlling the nominal life of the building also expresses constructive knowledge document, designed for for archaeological artef per le Costruzioni of 2
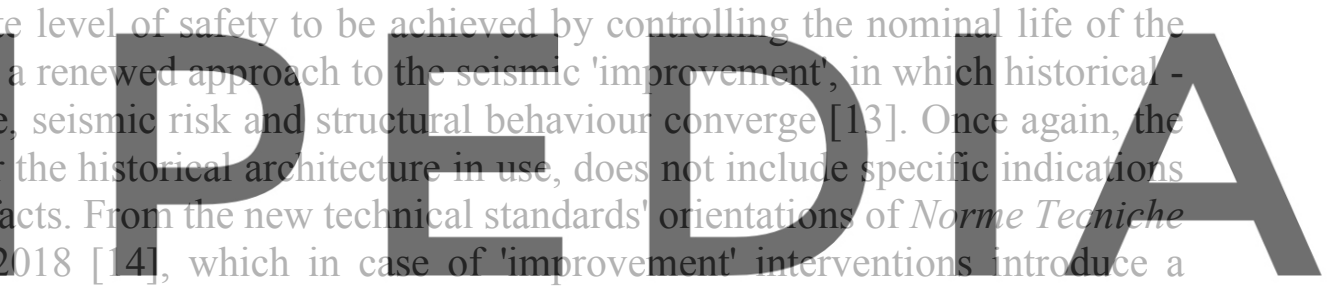

minimum safety value to be reached according to the building class of use, it emerges that the

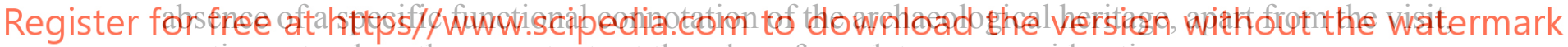
continues to place these contexts at the edge of regulatory reconsiderations.

From the evolutionary scheme outlined, alongside the significant progress made towards the conservation of cultural heritage, emerge the open problems and possible lines of development. Undoubtedly, archaeological pre-existences take on a priority place, whose conservation does not depend only on a methodologically correct project approach, but on the territorial vulnerability knowledge towards the seismic risk, to which this paper is dedicated.

\subsection{The Linee Guida Mibact 2011 and the three risk assessment levels}

The Linee Guida Mibact 2011 articulate the assessment of seismic risk on three distinct levels. Starting from some analysis which govern the territorial scale ('LV1' type), we move on to more detailed assessments conducted on the architectural scale ('Lv2' and 'Lv3' type).

The simplified evaluation system ' $\mathrm{L}_{V 1}$ ', suitable for a large area rapid control, estimates the structural collapse acceleration through limited geometric and mechanical parameters and using qualitative tools like the visual interrogation and the critical survey. Given the limited level of knowledge, are adopted low ' $\mathrm{Cc}^{\prime}$ confidence factors. The evaluation systems referring to the 'Lv2' and 'Lv3' levels, suitable for more complex analyses, requires the identification of the 
historical and construction specificities of the construction, an accurate characterization of the mechanical properties of the materials, and greater precision of geometric relief.

The 'LV1' analysis models, based on the qualitative interpretation of seismic behaviour by macroelements (architectural portions characterized by an autonomous behaviour with respect to the rest of the building [15]), are introduced for three architectural typologies like palaces, churches and towers, not contemplating archaeological structures.

\subsection{The Linee Guida per la conservazione di architetture di interesse archeologico (Guidelines for the conservation of architectures of archaeological interest)}

To deal with the emergency that hit the archaeological area of Rome and Ostia Antica in 2008, with widespread conservation problems due to the rapid progression of the risk of collapse, a working group was set up and coordinated by Roberto Cecchi, who drafted the Schema di Linee Guida per la conservazione di architetture di interesse archeologico [16]. This document represents the most up-to-date status of studies on the assessment and reduction of seismic risk relating to archaeological sites, because it complements the Linee Guida Mibact 2011 contents for a possible application to archaeological pre-existences. The methodological peculiarity consists in combining the knowledge path proper to the stratigraphic analysis of the elevated with the structural analysis. Given the number of archaeological artefacts at risk, 'Lv1-type' assessments are used to define a preliminary ranking of territorial vulnerability.

Specifically for the archaeological artefacts made in itself, characterized by a behaviour similar

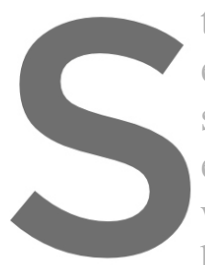
to that of historical

extended, defining seisn stratigraphic analysis

express the collapse ni

which, although coning

behavioural scheme.
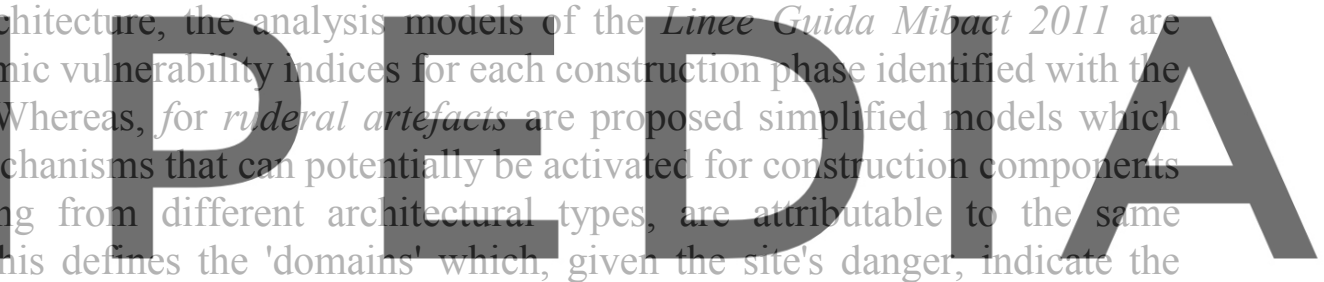

geometric and proportional characteristics of the archeological artefact beyond which the

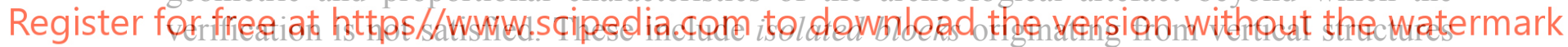

(columns and wall fragments), single arch structures (triliths or triumphal arches) and linear

systems (bridges, aqueducts). The applications carried out on some monuments demonstrate the strengths and limitations of this methodology. For the analysis of the Oratorio dei Quaranta Martiri, taken as artefact made in itself, the 'palaces' model is adopted, verifying the secondway mechanisms that engage the shear wall resistance. However, in a stratigraphically complex building with not always effective connections, collapse is more likely to occur due to off-plan mechanisms. The inspection activities carried out in 2011 on some Pompeii Domus [17] further develop the method, using the 'isolated blocks' domain of the ruined artefacts. This approach, methodologically opposite to the previous one, assesses the safety of the entire complex by verifying that the slenderness of each wall does not exceed that limit, ignoring the contribution offered by the connections. While recognizing the difficulty in simulating the real behaviour of the architectural complex, even in this case modelling involves significant approximations.

In general, it is clear that the path of knowledge proposed by the Schema di Linee Guida at the territorial scale, strongly anchored to the tools of stratigraphic analysis, is weakly connected to the analytical dimension, renouncing the control of material and conservative aspects in favour of primarily geometric factors. If what has been illustrated so far represents a step forward 
towards the characterization of rapid analysis tools specific to archaeology, below it is an attempt to implement the state of the art which tries to best combine the knowledge system with the analytical dimension.

\section{A METHODOLOGY FOR SPEDITIVE READING OF VULNERABILITY}

The proposed methodological approach aims to a speedy assessment of the seismic vulnerability of archaeological pre-existences [18]. To define a reading methodology based on a knowledge system calibrated according to archaeological specificities, this study presents some results obtained with applications conducted on structures and architectural components of the Roman Forum. Leaving aside the ruins made in itself, which show an overall structural behaviour attributable to that of historic buildings still in use, and for which the Linee Guida Mibact 2011 indications are generally considered valid, attention has been focused on ruins made up of walls without connections, whose structural behaviour, far from the global one, is in itself comparable to that of a 'macroelement'. It should be remembered that in the architectural context some experiences, such as the 1976 Friuli earthquake, promoted an important analysis of the effects generated by the earthquake, allowing the identification of precise breakdown mechanisms and recurring behavioural patterns for some building types. On the contrary, in an archaeological context, there is no real systematization of the structural behaviour of the ruins in the event of an earthquake. For this reason, direct observation conducted in a sample site such as the Roman Forum represented an essential step for identifying the main structural types. Believing that the stratigraphic reading involves significant difficulty in relating a need to carry out a 'morphologies-types' to facilitate the identifica archaeological pre-existence.
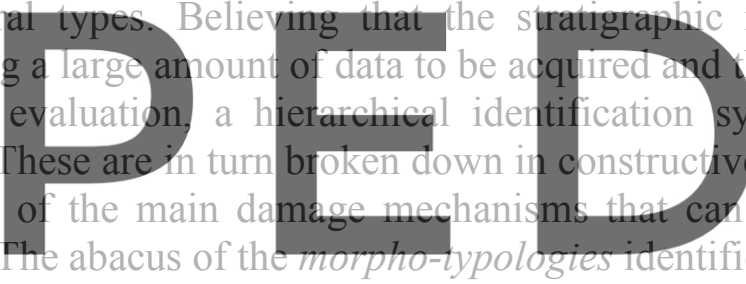

typologies, such as vertical structures (columns, pillars and masonry fragments), and the more

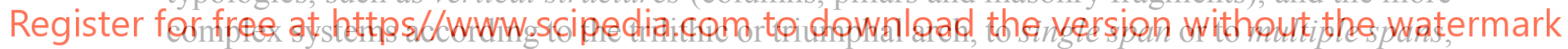
called linear systems. For the ruderal structures originated from the masonry buildings, depending on the different level of conservation it is possible to identify incomplete, complete or aggregate masonry cells. For the ruins originated from the remains of masonry buildings, depending on the different level of conservation observed, it is possible to identify incomplete wall cells (which at least preserve the angular connections between the walls); complete masonry cells (in which the walls bordering the base cell and possible horizontal connections are preserved); aggregate wall cells (with reciprocal connections between buildings).

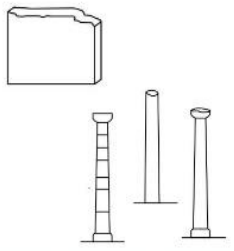

VERTICAL STRUCTURES
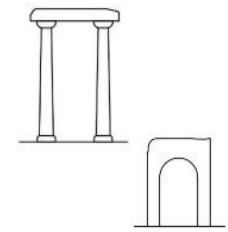

SINGLE SPAN STRUCTURE
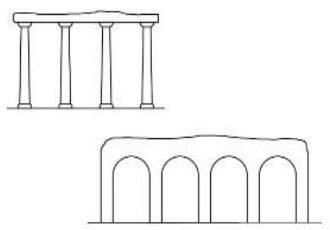

LINEAR SYSTEMS

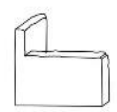

INCOMPLETE CELLS

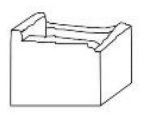

COMPLETE CELLS

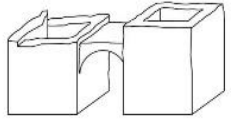

AGGREGATE CELS

Figure 1: Diagram of the morpho-typologies identifiable in an archaeological site 
In the north-western and central quadrant of the Roman Forum, components and buildings sample were identified, as representative as possible of each morphology-type.

The structures analysed include nine isolated columns (the Colonna di Foca, the two Colonne Onorarie, the columns facing the Via Sacra, the columns in front of the Tempio di Romolo and two columns of the Basilica Emilia), four linear structures (Tempio di Vespasiano, Tempio di Saturno, Tempio dei Castori, Portico degli Dei Consenti), and various wall cells with different levels of articulation and complexity belonging to the complex of the Casa delle Vestali. The direct reading conducted on the site was supported by the use of appropriate speedy and flexible scheduling traces (the main section of which are declinable according to the specific features of each structural 'morpho-typology') and, at the same time, homogeneous in the basic structure, making it possible to compare heterogeneous structures. Therefore, starting from models already tested by Mibact, the sections necessary for the structural aspects have been developed. To the specifically registry section, follows the one that registers the presence of provisional coverings, the conditions of access and approach to the monument and the presence of valuable elements. Two sections describe the site's morphology and its seismic chronology respectively. A subsequent part is dedicated to the geometric identification of the macroelements, indicating the main geometric parameters and the external constraint conditions. Following are the materials, the state of conservation and the dimensions of each construction element making up the 'morpho-typology' examined. For each of these are also investigated the effectiveness and state of conservation of the consolidations resulting from previous interventions (metal clamps, pins, chains, circles, material additions etc.); mutual connections between the parties deterioration signs and the elements etc.); the o are dedicated respectively to the description of the results.
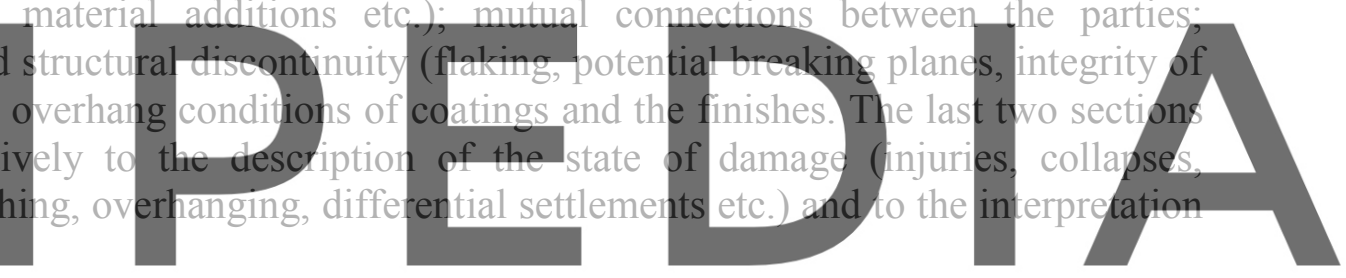

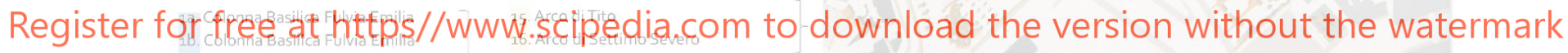
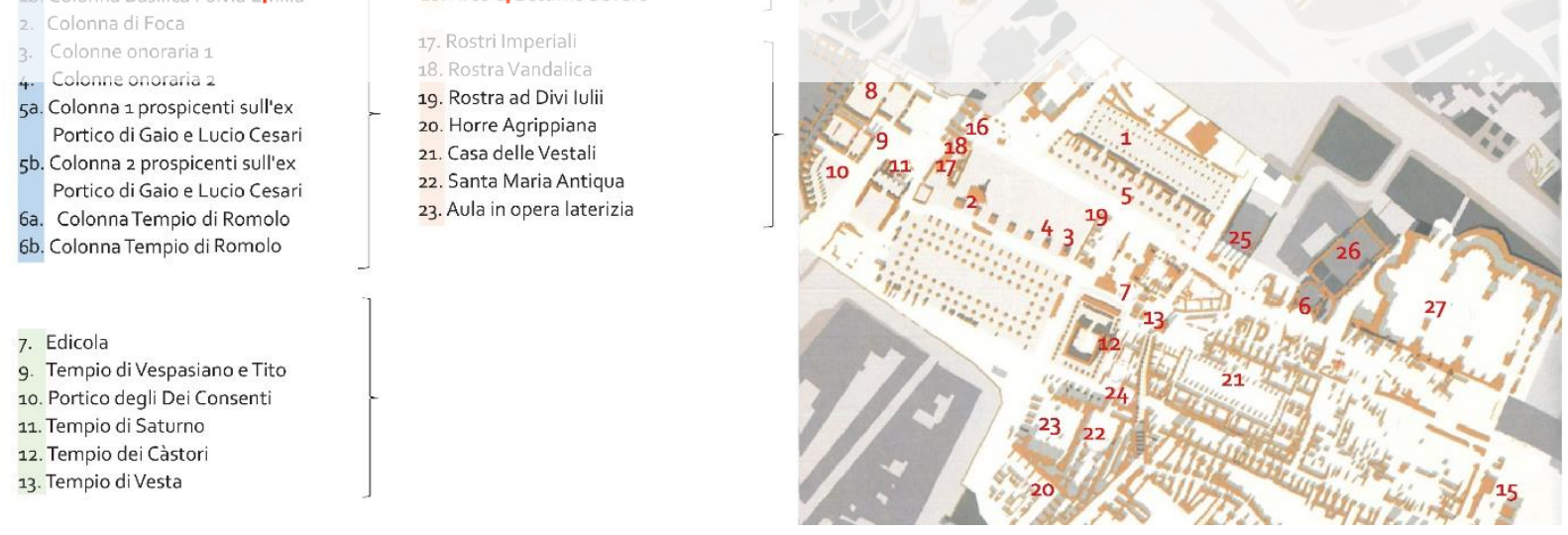

Figure 2: Localization of the monuments analysed in the Roman Forum

Through the reorganization of the data collected with the scheduling activity, concerning the isolated columns, the recurring aspects that prefigure conditions of vulnerability have been highlighted, diversified according to the characterization of the shaft (monolithic or articulated 
in drums). These include the reduction of the resistant section caused by the gaps in the shaft, the presence of reintegration sections and the bad contact between the drums.

Geometric features such as slenderness and top projections that influence global vulnerability are associated with the material - construction evidence. Specifically, the presence of various sections fractured and reintegrated with mortar was found for some of the highest columns of the Basilica Emilia with monolithic shafts; a misalignment, albeit slight, of the drums of the Colonna di Foca and the first Colonna Onoraria (for which the presence of pivots is ignored) and various fractures and partitions in correspondence with the second Colonna Onoraria.

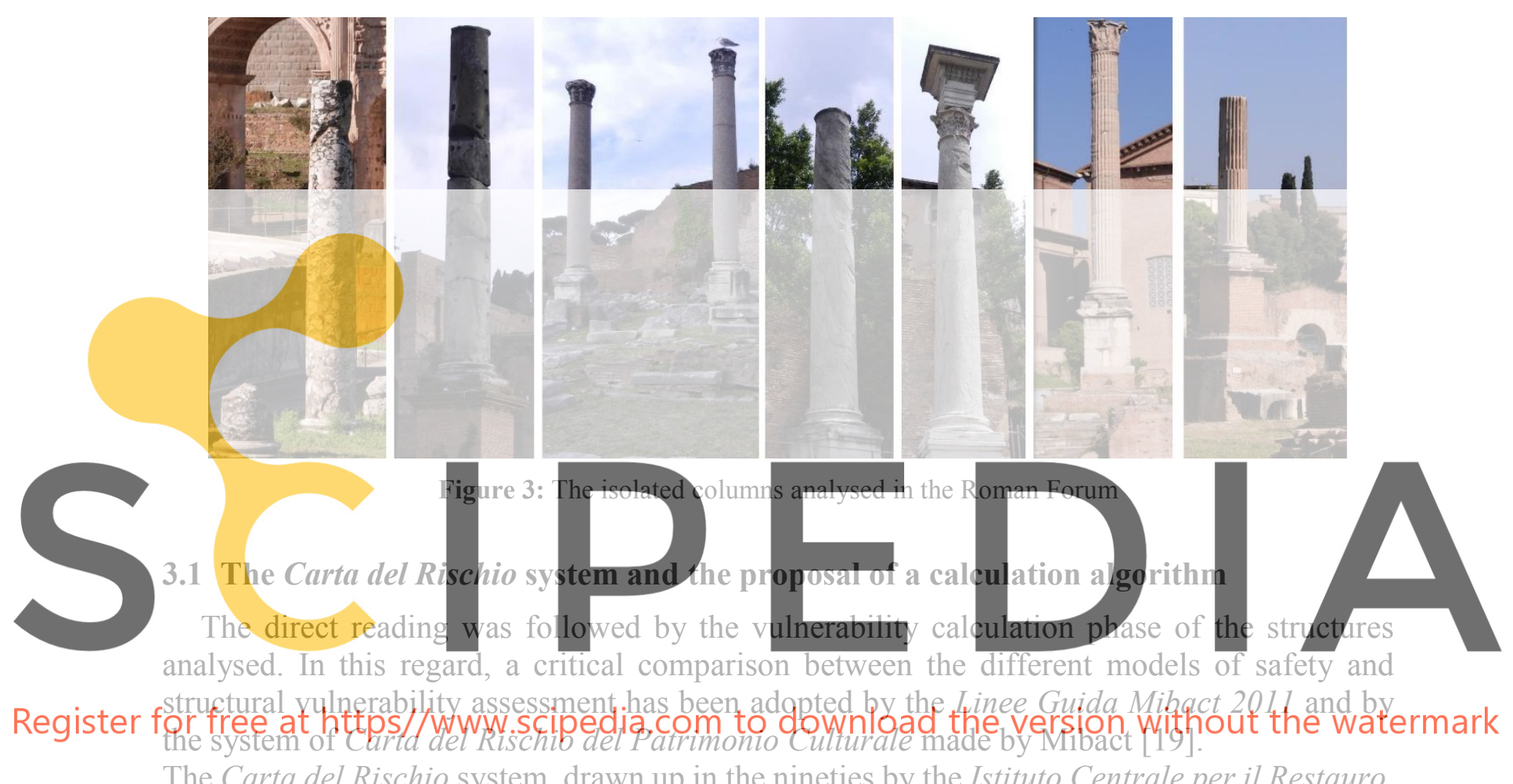

has made the concept of "preventive restoration" formulated by Cesare Brandi, intending to define a rapid identification system for the most exposed monuments and the ones at risk of loss, to plan intervention priorities objectively. If the Linee Guida Mibact 2011 set the structural verification on the calculation of the safety index (concerning the acceleration that leads to the collapse of the structure and the peak acceleration characteristic of the site), the Carta del Rischio system expresses this according to the architectural vulnerability and the territorial danger. For archaeological constructions, the vulnerability is estimated with the support of the 'Scheda Manufatto Archeologico', which observes for each construction element of the preexistence six different forms of material and surface degradation, contemplating, only in general, the specific structural problems [20]. From the comparative framework conducted, it was decided to set the seismic risk assessment according to a coherent methodology with the operative model of the Carta del Rischio system and, at the same time, calibrated according to the setting already illustrated for an 'Lv1' analysis regulated by the Linee Guida Mibact 2011. 
The development of a spreadsheet, connected to the previously illustrated scheduling layouts, has allowed the calculation of the vulnerability index for each structure investigated through an algorithmic formulation that is exemplified here for the isolated column morpho-typology.

The structure of the algorithm takes up the approach adopted in the Carta del Rischio system and in previous experiences in managing the cultural heritage $[21,22]$. The vulnerability is calculated as a weighted average of 5 sub-indices, each of which depends on variables depicted with the scheduling made on the site. The value of each variable is included in a range of six intervals. The sub-inches are calculated as the arithmetic average of the variables on which they depend. The arithmetic average represents an initial setting, which is subject to changes downstream of the appropriate validation of the schedules. The direct on-site study highlighted the main critical issues that affect the vulnerability of an archaeological artefact, such as the geometric relationships between the overhangning parts; the quality of the connections; the state of damage of the construction elements; etc. To each of these parameters, has been assigned a sub-index

The first sub-index registers the geometric parameters that have a moderate incidence in the activation of a rigid body mechanism such as slenderness; the second evaluates the connection and reinforcement elements present and the basic constraint conditions; the third records the structural discontinuities through variables such as the integrity of the sections, the deterioration of the materials and the presence of breakage planes; the fourth takes into account the presence of protrusions and overhangs that can influence the activation of the mechanism; the fifth

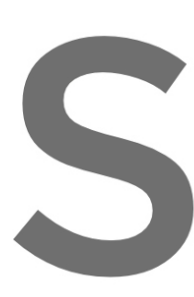
registers, for each constr sub-index is currentl which it depends, which

The direct study, for example, facilitated

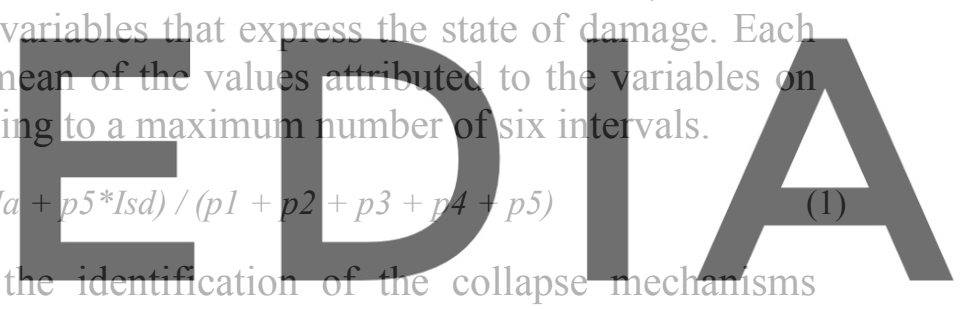
potentially activated for the isolated column morpho-typology, useful for calibrating the

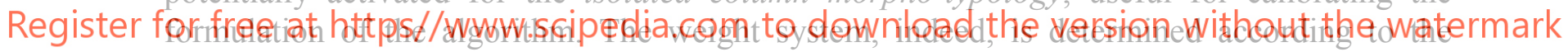
incidence that each sub-index is believed to assume in activating the most plausible and heavy damage mechanisms, as will be seen with an example. Through iterative corrections, an attempt was made to improve the architecture of the algorithm, to make it more able to grasp the constructive and conservative specificities that influence the structural behaviour of each column. A further revision and calibration level are currently in progress, entrusted to the comparison of the results from the 'Lv1' type analysis conducted, with those of a more accurate 'LV2' analysis, which governs the architectural scale, performed on some sample structures. The first index is based on a limited number of qualitative and quantitative parameters taken from direct reading; the second index, instead, requires the identification of the historical and constructive specificities, a more careful characterization of the materials mechanical properties, and a more accurate relief.

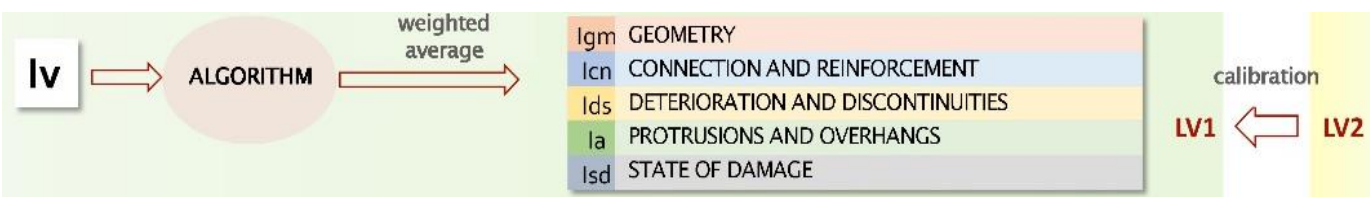

Figure 4: Architecture of the calculation algorithm 


\subsection{Example for the Colonna di Foca}

The marble column of the Corinthian order, erected in the central sector of the Forum in 608 AD. in honour of Emperor Phocas, through the assembly of recovery elements from a thirdcentury monument, represents the last monument erected in the Roman Forum [23]. It consists of seven grooved drums and stands 13.60 meters high on a marble-covered plinth placed on a brick-lined cement base, once hidden by a wide staircase leading up to the podium, currently poorly preserved. From the compilation of the schedule, more critical elements emerged such as the misalignments of the drums (which could prefigure preferential planes of rotation or sliding between the elements) and the significant inclination of the shaft. Doubts remain about the presence of pivots between the elements, not directly deducible with the visual investigation. The historiographic and technical documentation available has confirmed that the inclination of the column was caused by a serious alteration of the support surfaces. As is known, the column, which remained buried for a long time up to the base of the shaft, was completely brought to light during the nineteenth-century excavations [24, 25]. Probably, during the long burial period, the bedding layers of the marble slab placed as an elevation of the podium must have suffered disruptions, causing the fracture of the slab itself, the reduction of the support areas with the podium below and the consequent rotation of the shaft. The archival documentation indicates that in 1980 the continuity of support was restored with mortar additions, without, however, restoring the axiality of the shaft.
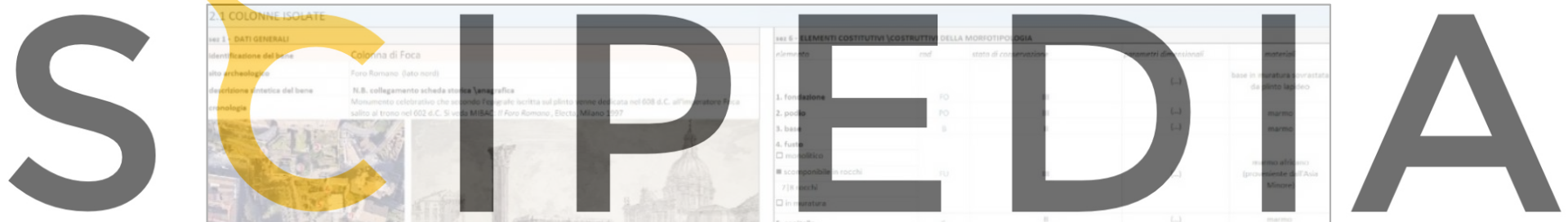

Register for free at https//www.scipedia.com to download the version without the watermark

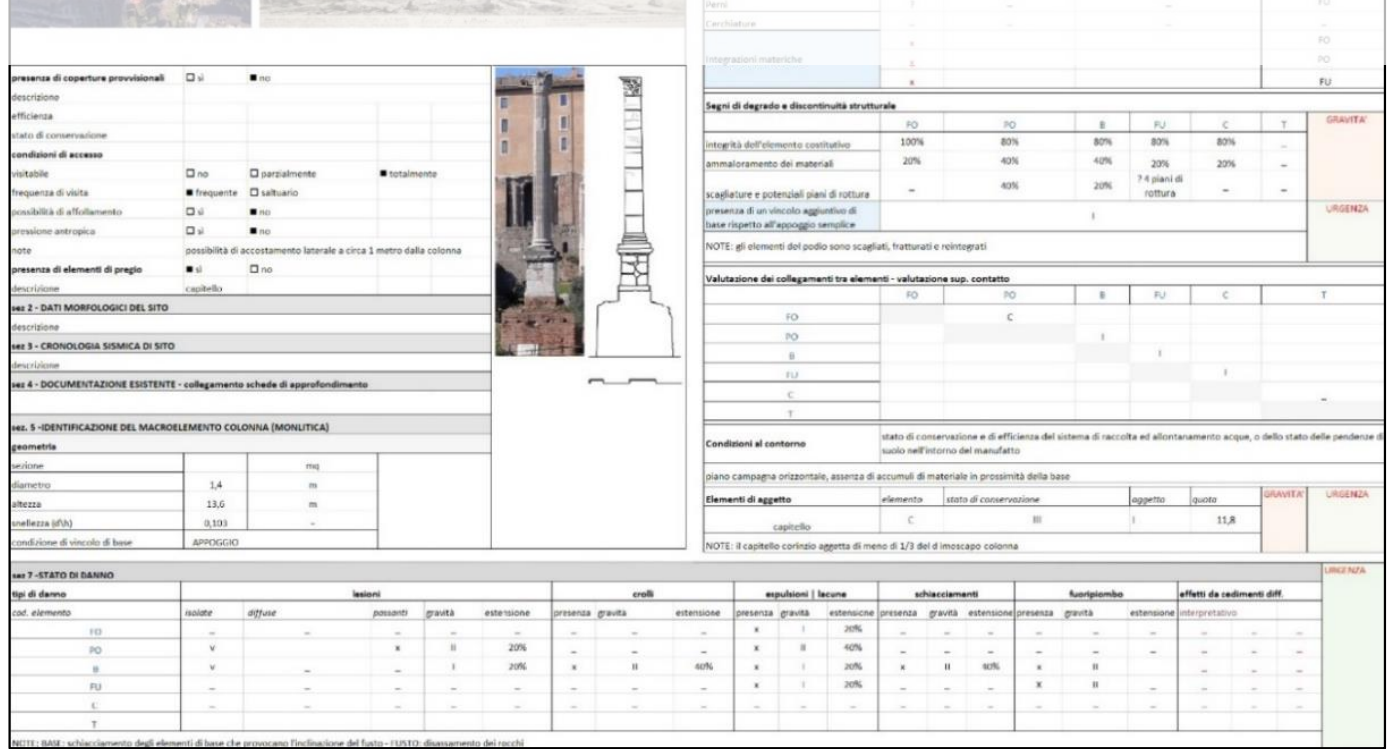

Figure 1: Scheduling traces Colonna di Foca 
For the construction of the algorithm, it is observed that the first sub-index ('Igm'), linked to the geometry, assumes a rather high value, equal to 0.6 , due to the slenderness of the column greater than $1 \backslash 10$. The second sub-index ('Icn'), however, given the uncertain presence of pivots between the stem's drums and on the nature constraint with the base and the upper capital, assumes a lower value, equal to 0.3. Even lower is the third sub-index ('Ids'), linked to the degradation and structural discontinuities of the elements, recently integrated, as it has been ascertained. The projection of the capital with respect to the shaft and the related out of plumb determine a value for the fourth sub-index ('Ia') equal to 0.4. The last sub-index ('Isd'), which records the damage status for each element, is approximately equal to 0.3 . Based on appropriate reflections on the collapse mechanisms of a column divided into drums, the weights to be attributed to each sub-index were set. If the horizontal sliding is subordinate to the nature of the connections between the drums (in this case unknown), the overturning of the entire shaft or parts of it can be influenced by misalignments, overhangs and slenderness. Based on the evidence found, weights have been assumed that are useful for conducting a weighted average between sub-index, determining, as follows, the final vulnerability index.

$$
W=(0,4 * 0,6+0,1 * 0,317+0,1 * 0,213+0,2 * 0,4+0,2 * 0,313) /(0,4+0,1+0,1+0,2+0,2)=0,438
$$

In general, the vulnerability obtained for the columns is consistent with what emerged from the direct knowledge gained during the first data collection. The most vulnerable structures include

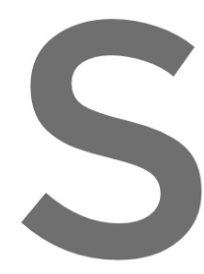
the Colonna di Foca an and state of damage, ext the Tempio di Romolo considerable overhang remaining columns, although different in geo
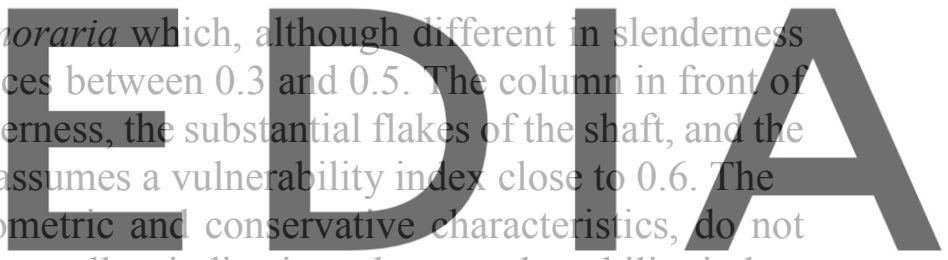

present particularly compromised conditions, as well as indicating a lower vulnerability index.

Register for free at https//www.scipedia.com to download the version without the watermark

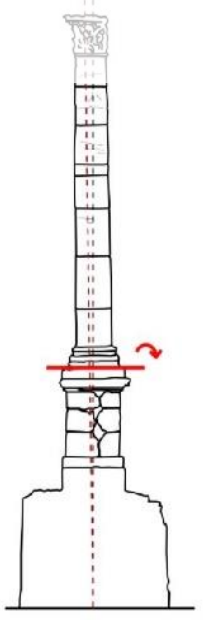

$\mathrm{Cl}$

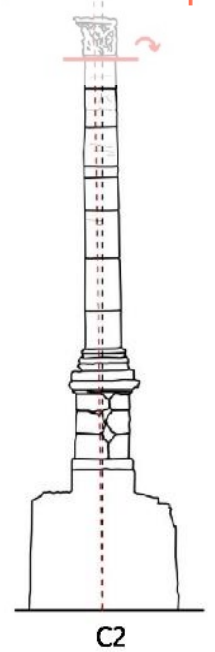

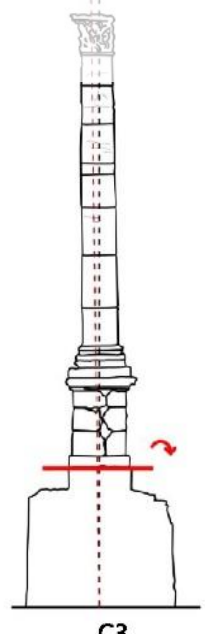

C3

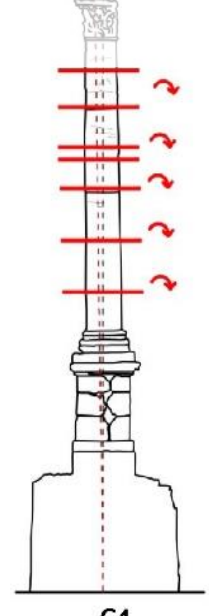

C4

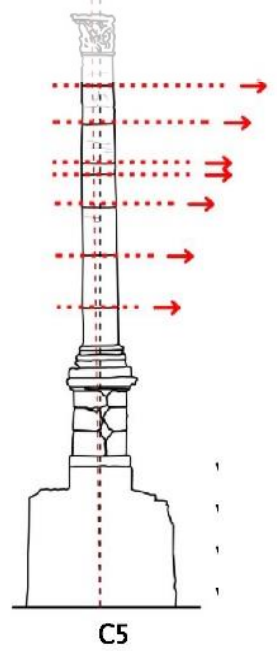

C5

Figure 6: Schematization of possible collapse mechanisms for the Colonna di Foca 


\section{CONCLUSIONS}

The illustrated methodology finds space in the complex relationship between conservation and structural safety that the regulatory excursus reflects. Although in development, it offers the possibility of integrating existing tools for the rapid assessment of the seismic risk of archaeological pre-existences, combining the deck of the Linee Guida Mibact with the Carta del Rischio. The set of knowledge, articulated around specific scheduling layouts, appropriately relates to the analytical dimension, through algorithmic formulations with the high management capacity of input data, as tested in initial and more recent experiences [26]. It should be remembered that the formulations exemplified for the isolated columns analysed are based on first working hypotheses and require appropriate checks and validations [27]. Lastly, it is believed that the evaluation of particularly vulnerable structures such as archaeological preexistences represents a complex problem that cannot be trivialized with extremely simplistic solutions. Therefore, through the use of confidence factors, in full consistency with the Linee Guida Mibact 2011, the system designed for an 'Lv1' level of analysis, is suitable for managing a more complex knowledge coming from the Mibact databases available and the historiographic study, which importance in structural safety assessments must not be overlooked.

\section{REFERENCES}

[1] A. De Ioanna, F. Picarreta: Il consolidamento antisismico nell'edilizia del XVIII e XIX secolo: regole dell'arte e processo evolutivo della normativa antisismica: le fonti storiche d'archivio a riscontro con l'osservazione in situ in "Palladio", n.s., XIII, 26 (2000), pp. 93 - 124;

[2] S. Lagomarsino: La nuova normativa sismica è buona per il resturo? in "Responsabilità della conservazione del costruito storico - Atti del convegno per il ventennale dell'Arco", Gangemi, Roma (2011), pp. 95 - 106;

[3] R. D. 18.04.1909 n.193, Norme tecniche ed igieniche obbligatorie per le riparazioni, ricostruzioni e nuove costruzioni degli edifici pubblici e privati nei luoghi colpiti dal terremoto del 28.12.1908 e da altri precedenti elencati nel R.D. 15.04.1909 (G.U. 22.04.1909, n.95);

[4] Legge 1.06.1939, n.1089, Tutela delle cose d'interesse Artistico o Storico, (G.U. 8.10.1939 n.184);

[5] D.M.LL. PP. 2.07.1981 Normativa per le riparazioni ed il rafforzamento degli edifici danneggiati dal sisma nelle regioni Basilicata, Campania e Puglia (G.U.21.07.1981 n. 198 suppl.);

[6] Circolare M.BB.CC.A. 18 luglio 1986, n. 1032, Comitato nazionale per la prevenzione del patrimonio culturale dal rischio sismico, Interventi sul patrimonio monumentale a tipologia specialistica in zone sismiche: raccomandazioni;

[7] D.M.LL.PP. 24.01.1986, Norme tecniche relative alle costruzioni antisismiche, (G.U. 12.05.1986 n. 108);

[8] R. Argalia, G. Augusti (a cura di): L'ingegneria sismica in Italia, 1991: atti del $5^{\circ}$ Convegno Nazionale: 29 settembre-2 ottobre 1991, Facoltà di Ingegneria, Università degli studi di Palermo, Esagrafica, Roma (1991);

[9] D.M.LL.PP. 16.01.1996, Norme tecniche per le costruzioni in zone sismiche, (G.U. 05.02.1996 n. 29);

[10] O. P. C. M. 20.03.2003 n. 3274, Primi elementi in materia di criteri generali per la classificazione sismica del territorio nazionale e normative tecniche per le costruzioni in zona sismica; 
[11] D. M. I. T. 14.01. 2008, Norme Tecniche per le Costruzioni, (G.U. 04.02.2008 n. 29);

[12] D. P. C. M. 9.02. 2011, Valutazione e Riduzione del rischio sismico del patrimonio culturale con riferimento alle Norme Tecniche per le Costruzioni di cui al D. M. Infrastrutture e Trasporti del 14 gennaio 2008, (G.U. 26.02.2011 n.47 - suppl. ord. n. 54);

[13] S. Lagomarsino: Linee Guida per la protezione del patrimonio culturale dal rischio sismico in "Quale sicurezza per il patrimonio architettonico? - atti del VI Convegno Nazionale Arco (Mantova 30/11 - 2/12 2006), Nuova Argos, Roma (2007), pp. 70 - 89;

[14] D. M. I. T. 17.01.2018, Aggiornamento delle "Norme Tecniche per le Costruzioni", (G.U. 20.02.2018 n.42 - suppl. ord. n. 8);

[15] F. Doglioni, A. Moretti, V. Petrini: Le chiese e il terremoto - Dalla vulnerabilità constatata nel terremoto del Friuli al miglioramento antisismico nel restauro, verso una politica di prevenzione, Edizioni LINT, Trieste (1994);

[16] R. Cecchi: Schema di Linee Guida per la conservazione di architetture di interesse archeologico in "Roma Archaeologia: interventi per la tutela e la fruizione del patrimonio archeologico: terzo rapporto", vol. 1 - 2, Electa, Milano (2011);

[17] R. Cecchi: Pompei Archaeologia, progetto di conservazione e fruizione del patrimonio archeologico, Electa, Milano (2011);

[18] This study is the result of a PhD research in progress in History, Design and Restoration of Architecture - XXXIII cycle (cv restoration) - Department of History, Design and Restoration of Architecture of the Sapienza University of Rome (Italy); supervisor: Prof.ssa D. Fiorani, co-supervisors: Prof.ssa A. Donatelli, Prof. F. De Cesaris;

[19] ICR: La Carta del Rischio del Patrimonio Culturale, Bonifica s.p.a. (1997);

[20] C. Cacace, A. Ferroni: Carta del Rischio: La vulnerabilità Archeologica in "Apparati Musivi Antichi nell'area del Mediterraneo", Atti del Convegno Internazionale di Studi (Piazza Armerina 9-13 aprile 2003), Quaderni di Palazzo Montalbo n4, Dario Flaccovio, Palermo (2004), pp 466472;

[21] R. Coppi: Metodologia per la costruzione dei modelli di rischio del Patrimonio Culturale in "La Carta del Rischio del Patrimonio Culturale", Bonifica s.p.a.,(1997);

[22] A. Donatelli: Addenda: Considerazioni per la definizione degli algoritmi per le schede di Unità Urbana in "Il futuro dei centri storici. Digitalizzazione e strategia conservativa" (di D. Fiorani), Quasar, Roma (2019);

[23] MIBAC: Il Foro Romano, Electa, Milano (1997), pp. 33 - 34;

[24] Archivio del Parco Archeologico del Colosseo and Archivio Storico di Palazzo Altemps in Rome.

[25] Soprintendenza archeologica d Roma: Forma. La città antica e il suo avvenire, De Luca Editori d'Arte, Roma (1985), pp. 83 - 86;

[26] D. Fiorani: Il futuro dei centri storici. Digitalizzazione e strategia conservativa, Quasar, Roma (2019);

[27] P. Angeletti, A. Bianchi, C. Cacace, A. Donatelli, O. Ceistllini, E. Rasimelli: Un metodo speditivo di valutazione della vulnerabilità e del rischio sismico di beni culturali. Caso di studio: Sicilia e Calabria in "Atti del XIII convegno ANIDIS" (Bologna, 28 giugno-2 luglio), (2009), sessione 4.1, cdrom. 